\title{
Investigation of Radioactive Environment in Open Park in a City
}

\author{
Xu Zhao, Yu Liu, Qiushi Liu \\ Sichuan Province Key Laboratory of Applied Nuclear Techniques in Geosciences, Chengdu University of Technology, Chengdu, \\ China \\ Email: zxu0817@163.com
}

How to cite this paper: Zhao, X., Liu, Y. and Liu, Q.S. (2020) Investigation of Radioactive Environment in Open Park in a City. Open Access Library Journal, 7: e6678. https://doi.org/10.4236/oalib.1106678

Received: July 29, 2020

Accepted: August 18, 2020

Published: August 21, 2020

Copyright ( $\odot 2020$ by author(s) and Open Access Library Inc.

This work is licensed under the Creative Commons Attribution International License (CC BY 4.0).

http://creativecommons.org/licenses/by/4.0/

\begin{abstract}
Urban parks provide citizens with fitness and leisure space, and their radioactivity affects every surrounding resident. In this paper, seven typical open parks in a city were selected and 350 measuring points were arranged in total, where the field gamma air radiation absorbed dose rate was measured by a portable X-gamma dosimeter. The results show that the surface gamma radiation absorbed dose rate of air ranges from $73.0 \mathrm{nGy} / \mathrm{h}-140.0 \mathrm{nGy} / \mathrm{h}$, and the average value ranges from $96.0 \mathrm{nGy} / \mathrm{h}-113.0 \mathrm{nGy} / \mathrm{h}$. Meanwhile, the calculated annual effective dose per capita ranges from $0.12 \mathrm{mSv}-0.14 \mathrm{mSv}$, which is far less than the average level of China $(0.54 \mathrm{mSv})$ and the global average level $(0.48 \mathrm{mSv})$. And the external exposure index due to surface nuclides is less than the limits required by national standards.
\end{abstract}

\section{Subject Areas \\ Nuclear Physics}

\section{Keywords}

Open Park, Gamma Radiation Absorbed Dose Rate, Natural Radionuclides, Annual Effective Dose

\section{Introduction}

The radioactive environment is an important part of the natural environment, which is full of radiation. Thus, the public is exposed to ionizing radiation mainly from natural radioactivity in the environment (cosmic rays and proto-radionuclides) [1]. Due to various factors, the natural radioactivity levels in nature vary greatly in different regions [2].

Parks are the first choice, when people go for a walk outside, where are the 
closest to nature in the city. Therefore, a scientific and reasonable evaluation of the content of radionuclides in the environmental media and in the typical open park of the city and the radiation dose caused by the public can provide a basis for the construction of the city in terms of the natural radioactive environment.

In this paper, the level of radioactivity in the open parks was studied to determine the source of the radiation, whether there were potential pollution hazards, and the impact on human health, by measuring the absorbed dose of air in the parks [3].

\section{Research Contents and Methods}

\subsection{Research Contents}

The surface gamma radiation absorbed dose rate of environmental radiation measurements were carried out in different open parks in various urban areas. By processing and analyzing these data (Table 1), the radiation environment in the open parks was preliminarily evaluated to determine the source of radiation and whether there were potential pollution hazards, and to understand the radiation level of some open parks in the city and the impact on the surrounding residents.

\subsection{Research Methods}

1) Select 7 open parks in the city as the target areas;

2) Process the stability test of the measuring instrument;

3) Determine the number of grid measuring points according to the size of the park and the functional area within the park, and conduct on-site gamma total measurement;

4) Analyze and process data, estimate experimental errors, and calculate annual effective dose.

\subsection{Data Processing Method}

According to the radiation Protection regulations of GB8703-1988, the annual effective dose equivalent of members of the public is $5 \mathrm{mSv}$ per year as the dose limit. Estimation of the absorbed dose rate of environmental Gamma radiation the per capita annual effective dose generated by gamma radiation on the population is calculated by Formula (1) [4].

$$
D_{\text {aed }}=D \times a_{1} \times a_{2} \times t
$$

where: $D_{\text {aed }}$ is average annual effective dose of external gamma radiation, unit:

Table 1. Radioactivity measurement content.

\begin{tabular}{lccc}
\hline Environmental media & Measurement content & $\begin{array}{c}\text { Number of } \\
\text { measuring points }\end{array}$ & $\begin{array}{c}\text { Survey target } \\
\text { area }\end{array}$ \\
\hline the earth's surface & Gamma radiation dose rate & 350 & 7 parks \\
\hline
\end{tabular}


$\mathrm{mSv}$; $D$ is air absorbed dose rate value of external gamma radiation at $1 \mathrm{~m}$ above ground, unit: $\mathrm{nGy} / \mathrm{h} ; a_{1}$ is the conversion coefficient between gamma absorbed dose and annual effective dose in the atmosphere is $0.7 \mathrm{~Sv} / \mathrm{Gy} ; a_{2}$ is the average residence factor of residents is 0.2 according to the object of study; $t$ is time spent in the environment, $1 \mathrm{a}=8760 \mathrm{~h}$.

\section{Natural Radioactivity Measurement Process}

\subsection{Survey of Target Areas}

There are more than ten open parks in the central area of the city, which are resident public places for leisure and fitness. In order to ensure sufficient representativeness of the survey target, 7 representative parks were selected in the end, with a large number of people served by the target park and basically perfect surrounding facilities [3].

\subsection{Layout of Survey Line in Survey Area}

On the basis of the geological and hydrogeological conditions in the open parks, the grid point distribution method is adopted. According to the size of the park, different functional areas and different population density, different point distribution density is adopted to measure the vertical surface of the site. The distribution point is $40 \mathrm{~m} \times 40 \mathrm{~m}$ grid for larger parks, and $15 \mathrm{~m} \times 10 \mathrm{~m}$ grid, or 25 $\mathrm{m} \times 25 \mathrm{~m}$ grid for smaller parks. Besides, properly encrypt measuring points at the area like rivers, ponds, buildings or closed areas in the park.

\subsection{Quality Assurance Measures}

The purpose of quality assurance is to ensure the authenticity of measuring data and the test area. Therefore, the following measures should be taken.

1) Instrument calibration.

The calibration of the instrument has been completed before leaving the factory, and the accuracy of the instrument was verified before this experiment.

2) Stability test of the instrument.

The radiation dose rate was measured at a fixed location in an open field, for two consecutive days, more than 20 groups were measured every day with an interval of $10 \mathrm{~s}$ and $180 \mathrm{~s}$ for each group containing 52 groups of data totally. The processing of test data is shown in Table 2.

\subsection{Measuring Process}

In accordance with the requirements of Specification for the Measurement of Dose rate of Ambient Ground Gamma radiation (GB/T 14583-1993) [5], in-situ gamma exposure air absorbed dose rate (D) was measured.

1) Set instrument parameters and preheat for $10 \mathrm{~min}$;

2) Place the tripod, place the probe on the tripod, set the calibration line (measured height) on the probe at a distance of $1 \mathrm{~m}$ from the ground, and set the detection time to $60 \mathrm{~s}$; 
Table 2. Analysis of stability measurement data of portable X- $\gamma$ dose rate meter.

\begin{tabular}{ccc}
\hline Measurement data & First day measurement data & Second day measurement data \\
\hline Average value $/ \times 10^{-8} \mathrm{~Gy} / \mathrm{h}$ & 31.79 & 32.23 \\
Mean square error & 0.37 & 0.34 \\
Skewness coefficient & 0.472 & 0.441 \\
Kurtosis coefficient & 0.918 & 0.858 \\
Maximum standard deviation & 0.02542 & 0.02715 \\
Standard deviation & 0.3763 & 0.3492 \\
Relative standard deviation & 0.01184 & 0.01083
\end{tabular}

Table 3. Information table of measuring points in each park.

\begin{tabular}{cccccc}
\hline Park name & $\begin{array}{c}\text { Measuring } \\
\text { time }\end{array}$ & Weather & $\begin{array}{c}\text { Number of } \\
\text { points }\end{array}$ & Serial number & Density of points \\
\hline Park A & April 21 & Sunny & 50 & SD01 SD50 & $40 \times 40 \mathrm{~m}$ \\
Park B & April 26 & Sunny & 50 & SBQ01 SBQ50 & $40 \times 30 \mathrm{~m}$ \\
Park C & April 27 & Sunny to cloudy & 50 & EXQ01 EXQ50 & $15 \times 10 \mathrm{~m}$ \\
Park D & April 28 & Sunny to cloudy & 50 & BH01 BH50 & $35 \times 25 \mathrm{~m}$ \\
Park E & April 29 & Cloudy & 50 & SH01 SH50 & $25 \times 25 \mathrm{~m}$ \\
Park F & April 30 & Sunny & 50 & BHT01 BHT50 & $40 \times 40 \mathrm{~m}$ \\
Park G & May 1 & Cloudy & 50 & NZ01 NZ50 & $40 \times 40 \mathrm{~m}$ \\
\hline
\end{tabular}

3) Measure and record data. (Record data for every three measurements)

The measurement points of each park are shown in Table 3.

\section{Result}

\subsection{Present Situation of Dose Rate Distribution of $\gamma$ Radiation}

This survey covers the whole range of 7 open parks (some areas of the park are rivers, reservoirs or buildings), with a total survey area of $394,300 \mathrm{~m}^{2}$ and 350 survey points in total. According to the measurement results, the contour map of gamma dose rate of each park was drawn, which shows the level of surface gamma dose rate in these 7 parks basically, and the results were shown in Table 4 below.

According to the above data, the surface gamma dose rate of some open parks in a city ranged $7.3 \times 10^{-8} \mathrm{~Gy} / \mathrm{h}-14 \times 10^{-8} \mathrm{~Gy} / \mathrm{h}$, and the average value ranged $9.6 \times 10^{-8} \mathrm{~Gy} / \mathrm{h}-11.304 \times 10^{-8} \mathrm{~Gy} / \mathrm{h}$, which was within the normal value of natural radioactivity level. The surface gamma dose rate of park E was obviously slightly higher than that of other parks, reaching the maximum value of $14 \times$ $10^{-8} \mathrm{~Gy} / \mathrm{h}$, while the value of other parks was basically the same.

The values obtained in this survey were all within the normal range of the province, while and the minimum values were increased, compared with the data from 1983 to 1990 , and the measured values were slightly above the annual 
average without exceeding the maximum, compared with the 2017 values. And the average gamma absorbed dose rate measured this time was $(3-4) \times 10^{-8}$ $\mathrm{Gy} / \mathrm{h}$, compared with the survey results of Zou Yulin et al. $\left(6.77 \times 10^{-8} \mathrm{~Gy} / \mathrm{h}\right)[6]$.

\subsection{Estimation of Annual Effective Dose of Public Natural Radiation}

The per capita effective dose was calculated from Formula 1, as shown in Table 5.

As shown in Table 5 that the per capita annual effective dose, by Formula (1), of some open parks in the city ranges from $0.12 \mathrm{mSv}$ to $0.14 \mathrm{mSv}$, which is far less than the average level of China $(0.54 \mathrm{mSv})$ and the global average level ( 0.48 $\mathrm{mSv})$.

\section{Conclusions}

In this paper, the natural radiation level of the open parks was investigated and evaluated systematically, where the surface gamma dose rate was measured by setting up 350 measuring points with different grid density. Based on the statistical analysis of these measured data, the radiation level of residents caused by surface gamma dose rate of typical open parks in the city was evaluated and studied in detail. The specific conclusions are as follows:

1) The low natural radioactivity level and the gamma absorbed dose rate, which is lower than the national standard medium limit $(1 \mathrm{mSv})$, in these typical

Table 4. Surface dose rate measurements (unit: $10^{-8} \mathrm{~Gy} / \mathrm{h}$ ).

\begin{tabular}{cccccc}
\hline Park name & Average value & $\begin{array}{c}\text { Maximum } \\
\text { value }\end{array}$ & $\begin{array}{c}\text { Minimum } \\
\text { value }\end{array}$ & $\begin{array}{c}\text { Standard } \\
\text { deviation }\end{array}$ & $\begin{array}{c}\text { Coefficient of } \\
\text { variation }\end{array}$ \\
\hline Park A & 10.1 & 10.8 & 8.5 & 0.434 & 0.043 \\
Park B & 10.5 & 11.5 & 8.3 & 0.684 & 0.065 \\
Park C & 9.9 & 12.1 & 7.3 & 1.042 & 0.105 \\
Park D & 9.6 & 10.6 & 8.6 & 0.548 & 0.057 \\
Park E & 11.3 & 14.0 & 8.7 & 1.471 & 0.130 \\
Park F & 10.4 & 11.8 & 9.4 & 0.520 & 0.050 \\
Park G & 10.6 & 12.7 & 9.2 & 0.722 & 0.068 \\
\hline
\end{tabular}

Table 5. Annual effective dose per capita.

\begin{tabular}{ccc}
\hline Park name & Average dose rate of $\gamma$ air absorption (nGy/h) & Annual effective dose (mSv) \\
\hline Park A & 101.0 & 0.12 \\
Park B & 105.0 & 0.13 \\
Park C & 99.0 & 0.12 \\
Park D & 96.0 & 0.12 \\
Park E & 113.0 & 0.14 \\
Park F & 104.0 & 0.13 \\
Park G & 106.0 & 0.13 \\
\hline
\end{tabular}


open parks environment of this city, indicate that the open park environment of this city is suitable for people to stay for a long time;

2) The residents' annual effective dose caused by environmental gamma radiation range between $0.12 \mathrm{mSv}-0.14 \mathrm{mSv}$, which is far less than the native average level $(0.54 \mathrm{mSv})$, global average $(0.48 \mathrm{mSv})$ and the national radiation protection standards $(1.0 \mathrm{mSv})$, means the open parks of the city's environmental gamma radiation in the level of security;

3) The distribution of environmental surface gamma dose rate in the open park of this city was between $73.0 \mathrm{nGy} / \mathrm{h}$ and $140.0 \mathrm{nGy} / \mathrm{h}$, with the average value between $96.0 \mathrm{nGy} / \mathrm{h}$ and $113.0 \mathrm{nGy} / \mathrm{h}$, slightly higher than the national average $(62.8 \mathrm{nGy} / \mathrm{h})$, without exceeding the maximum value. And there was no abnormal area of the dose rate of environmental surface gamma radiation by statistical analysis of the data, indicating that the environmental surface gamma radiation from the city's open park was at a normal level.

\section{Conflicts of Interest}

The authors declare no conflicts of interest regarding the publication of this paper.

\section{References}

[1] Tang, B., Ge, L.-Q., Fang, F., et al. (2011) Measurement, Principle of Nuclear Radiation. Harbin Engineering University Press, Harbin.

[2] Chun, S.T.W.X. (2012) Discussion on Regional Natural Radioactive Environmental Investigation Discussion on Regional Natural Radioactive Environmental Investigation and Evaluation Method. Uranium Mining and Metallurgy, 31, 214-216.

[3] Ruan, S.-Z., Zhao, Z.-X., Su, K.-J., et al. (2017) Investigation and Analysis about Radionuclide Level in Soil of Main Parks in Tianjin City. China Medical Equipment, 14, 83-86.

[4] Radiation UNSCEAR United Nations Scientific (1993) Exposure from Natural Sources of Radiation. United Nations, New York.

[5] Ministry of Environmental Protection, PRC. (1994) GB/T 14583-1993 Standard for the Determination of Environmental Surface Dose Rate. China Standard Press, Beijing.

[6] Zou, Y.-L. and Du, D.-Y. (2011) Investigation of Natural Radionuclide Contents in Soils of Chengdu. Sichuan environment, 30, 26-29. 